\title{
ANALISIS TRIWULANAN: \\ Perkembangan Moneter, Perbankan dan Sistem Pembayaran, Triwulan III - 2007
}

Tim Penulis Laporan Triwulanan, Bank Indonesia

Pada triwulan III-2007, perekonomian Indonesia diprakirakan tumbuh sebesar 6,3\%. Perkembangan perekonomian Indonesia secara umum sampai dengan triwulan III-2007 masih sesuai dengan perkiraan, meskipun sempat mendapat tekanan dari sisi eksternal terkait dengan krisis Sub Prime Mortgage di Amerika Serikat. Meningkatnya konsumsi serta ekspor menjadi faktor pendorong tumbuhnya perekonomian. Sementara itu, investasi juga diperkirakan akan tumbuh lebih tinggi. Membaiknya konsumsi didorong oleh perbaikan daya beli seiring dengan peningkatan pendapatan dan tren suku bunga yang menurun. Sementara peningkatan ekspor masih didorong oleh kuatnya permintaan dan tingginya harga komoditas global. Di sisi penawaran, seiring dengan tingginya pertumbuhan konsumsi dan ekspor, sektor industri pengolahan dan sektor perdagangan diperkirakan akan mencatat pertumbuhan yang tinggi.

Kinerja Neraca Pembayaran Indonesia (NPI) pada triwulan III-2007 secara keseluruhan diperkirakan masih mencatat surplus meskipun tidak sebesar surplus di triwulan II-2007. Surplus NPI tersebut terutama terjadi di sisi neraca transaksi berjalan yang didukung oleh peningkatan ekspor. Sementara itu, neraca modal dan finansial mencatat surplus yang lebih rendah akibat menurunnya aliran masuk modal asing sebagai dampak dari gejolak pasar keuangan global. Dengan kondisi ini, jumlah cadangan devisa pada akhir triwulan III-2007 tercatat sebesar USD52,8 miliar atau setara dengan 5,4 bulan impor dan pembayaran utang luar negeri Pemerintah.

Nilai tukar rupiah pada triwulan III-2007 secara rata-rata melemah dibandingkan triwulan II-2007 dengan volatilitas yang masih berada dalam level rendah. Rata-rata nilai tukar di triwulan III-2007 tercatat Rp 9.250 atau terdepresiasi 3,1\% dibanding triwulan II-2007 sebesar Rp 8.968. Terdepresiasinya nilai tukar rupiah lebih disebabkan oleh imbas gejolak pasar keuangan global. Namun, meredanya dampak gejolak global serta dukungan kuatnya faktor fundamental dapat kembali memposisikan nilai tukar rupiah pada tren apresiasi.

Tekanan inflasi di triwulan III-2007 tercatat lebih tinggi dibandingkan triwulan sebelumnya, walaupun diperkirakan tidak akan berlanjut dan hanya bersifat temporer/musiman. Secara 
tahunan inflasi IHK dan inflasi inti di triwulan III-2007 tercatat sebesar 6,95\% dan 6,03\%. Lebih tingginya inflasi pada periode tersebut terutama bersumber dari kelompok volatile food, seperti minyak goreng dan beras, yang antara lain disebabkan oleh meningkatnya harga input dan permintaan menjelang hari raya lebaran. Selain itu, kelangkaan minyak tanah dan kenaikan tarif jalan tol juga turut memberikan kontribusi pada peningkatan inflasi. Dari sisi eksternal, meningkatnya harga komoditi global dan pelemahan nilai tukar rupiah mendorong peningkatan inflasi inti di periode yang sama.

Penurunan suku bunga pinjaman dan suku bunga simpanan masih terus berlanjut di triwulan III-2007. Di tengah BI rate yang tidak mengalami perubahan, pada bulan Agustus 2007, suku bunga kredit modal kerja (KMK) dan kredit investasi (KI) tercatat sebesar 13,66\% dan 13,75\%, lebih rendah dibandingkan posisi pada akhir triwulan II-2007 sebesar 13,88\% dan 13,99\%. Sementara itu, suku bunga kredit konsumsi (KK) juga mengalami penurunan menjadi 16,70\% dibandingkan akhir triwulan sebelumnya sebesar 16,91\%. Di sisi penghimpunan dana, rata-rata suku bunga deposito periode 1 bulan pada bulan Agustus 2007 tercatat sebesar 7,16\% menurun dari 7,46\% di akhir triwulan II-2007. Tren penurunan suku bunga ini diikuti oleh membaiknya fungsi intermediasi dan indikator kinerja perbankan. Sementara itu, IHSG kembali meningkat pada September 2007 setelah sempat menurun cukup tajam pada akhir Juli sampai Agustus 2007 akibat pengaruh gejolak pasar keuangan global. Pada akhir triwulan III-2007, Indeks Harga Saham Gabungan (IHSG) tercatat mencapai 2.359, lebih tinggi dibandingkan akhir triwulan II-2007 sebesar 2.139. Membaiknya IHSG tersebut tidak terlepas dari terjaganya stabilitas makroekonomi dan membaiknya kondisi mikro perusahaan yang tampak pada pertumbuhan kinerja dan pendapatan emiten.

Ke depan, inflasi diperkirakan masih berada di kisaran sasarannya sebesar $6 \% \pm 1 \%$ di 2007 dan 5\% $\pm 1 \%$ di 2008. Meningkatnya tekanan inflasi di triwulan III-2007 diperkirakan hanya bersifat temporer dan musiman. Tekanan inflasi ke depan diperkirakan dapat dikendalikan walaupun terdapat tekanan inflasi yang bersumber dari faktor eksternal dan peningkatan permintaan seiring dengan prospek pertumbuhan ekonomi yang diperkirakan akan terus membaik bersamaan dengan komitmen Pemerintah untuk tidak menaikkan administered prices. Pertumbuhan tahunan PDB 2007-2008 diperkirakan sebesar 6,2\% dan 6,5\%, didorong oleh konsumsi dan ekspor yang tumbuh lebih tinggi. Investasi juga diperkirakan akan tumbuh lebih tinggi seiring dengan peningkatan kapasitas produksi untuk merespon kenaikan permintaan ke depan. Dari sisi eksternal, NPI diperkirakan masih mencatat surplus yang didorong oleh kuatnya ekspor terkait dengan pengaruh tingginya harga komoditi global.

Selanjutnya, Bank Indonesia akan terus mencermati serta mengantisipasi timbulnya beberapa risiko yang dapat menimbulkan potensi perlambatan pada perekonomian domestik 
serta peningkatan inflasi. Faktor risiko tersebut antara lain berupa perlambatan ekonomi di Amerika Serikat, berlanjutnya peningkatan harga minyak dan Crude Palm Oil (CPO), serta komoditas non-migas pertanian. Selain itu, berlanjutnya gejolak pasar keuangan global sebagai dampak dari krisis sub prime mortgage juga merupakan salah satu risiko yang tetap diwaspadai. Selain faktor eksternal tersebut, risiko juga dapat bersumber dari dalam negeri, seperti kelangkaan minyak tanah.

Dalam kaitan ini, Bank Indonesia akan tetap melaksanakan kebijakan moneter secara terukur dan hati-hati dengan terus mencermati berbagai dinamika perekonomian. Keputusan Bank Indonesia untuk mempertahankan BI-Rate pada tingkat 8,25\% didasari evaluasi yang dilakukan secara menyeluruh mengenai proyeksi dan perkembangan perekonomian, prospek pencapaian target inflasi untuk tahun 2007 dan 2008 yang masing-masing sebesar $6 \pm 1 \%$ dan $5 \pm 1 \%$ serta identifikasi terhadap faktor-faktor risiko yang ada. Bank Indonesia memandang, tidak berubahnya Bl-Rate pada tingkat 8,25\% masih mampu memberikan stimulus bagi pertumbuhan ekonomi Indonesia ke depan sejalan dengan masih tersedianya ruang gerak bagi bank untuk menurunkan suku bunga lebih lanjut. Di sisi lain, kebijakan tersebut juga dapat mengantisipasi risiko peningkatan inflasi ke depan yang didorong oleh peningkatan permintaan sejalan dengan pertumbuhan ekonomi yang lebih tinggi. 
halaman ini sengaja dikosongkan 